Department of Health (Republic of Ireland) (1950a). Dietary Survey of Large and Small Towns. Dublin: The Stationery Office.

Department of Health (Republic of Ireland) (1950b). Dietary Survey of Farming Families. Dublin: The Stationery Office.

Jessop, W. J. E. (1950). Brit. J. Nutrit. 4, 28 I.

\title{
Haemoglobin and Plasma-Protein Values in 2500 Adults and 600 Pregnant Women in the Republic of Ireland
}

\section{By T. E. Bradshaw, Royal College of Surgeons in Ireland, St Stephen's Green, Dublin}

Investigations were carried out on two groups of individuals. The first group consisted of adult men and women mostly from provincial districts of Ireland, who were anxious to migrate to Great Britain for the purpose of obtaining employment. The Irish Government considered it advisable for them to submit to a physical examination before leaving the country and insisted that this examination be carried out before a travel permit would be granted. The applicants for permits were examined in the evenings at two centres, one for men and another for the women. At the time of examination certain details were recorded which might be of interest in the Irish National Nutrition Survey (Department of Health (Republic of Ireland), I949a, $b$, I950a, $b$ ), and samples of $3 \mathrm{ml}$. venous blood were taken, transferred to an oxalated tube and sent by messenger to the Rotunda Hospital laboratory where haemoglobin estimations were carried out the same evening. In this group a total of 1107 males and 1432 females was investigated.

The second group consisted of women in various stages of pregnancy who were attending the Out-Patient Department of the Rotunda Hospital. As part of the hospital routine samples of venous blood are taken from all such patients, and in each of these cases a $3 \mathrm{ml}$. portion was transferred to an oxalated tube. Haemoglobin estimations were carried out the same evening. A total of approximately 600 samples was investigated.

In both these groups, plasma proteins were also determined on about half the total number of subjects.

\section{Methods}

In all cases haemoglobin estimations were done by the alkaline-haematin method. The colour intensities were determined in a Spekker absorptiometer against the Gibson-Harrison standard, kindly supplied by Prof. D. C. Harrison, Queen's University, Belfast. In a number of cases the haemoglobin was also determined by the acid-haematin method and good correlation was obtained.

In about half the number of each group, haemoglobin values and also plasma-protein values were obtained from the densities of the whole blood and plasma by the coppersulphate method of Phillips, Van Slyke, Dole, Emerson, Hamilton \& Archibald (1945).

\section{Results}

In Table $\mathrm{r}$ the results of the haemoglobin survey are given in such a way as to show the distribution of the values over the whole sample. The figures for adult men and women will be considered first. Though it is clear that the great majority of the subjects 
Table I. Distribution of haemoglobin values for men and non-pregnant and pregnant women

$\begin{array}{cccc}\begin{array}{c}\text { Men } \\ \text { Haemoglobin }\end{array} & \begin{array}{c}\text { Women } \\ \text { (percentage } \\ \text { of total) }\end{array} & \begin{array}{c}\text { Pri32) } \\ \text { (percentage } \\ \text { of total) }\end{array} & \begin{array}{c}\text { Pregnant } \\ \text { women }(600) \\ \text { (percentage } \\ \text { of total) }\end{array} \\ 5.0-5.9 & 0 & 0 & 0.4 \\ 6.0-6.9 & 0 & 0.1 & 0.2 \\ 7.0-7.9 & 0 & 0.2 & 0.8 \\ 8.0-8.9 & 0.1 & 0.7 & 1.6 \\ 9.0-9.9 & 0.3 & 0.8 & 5.2 \\ 10.0-10.9 & 0.4 & 2.4 & 12.4 \\ 11.0-11.9 & 0.6 & 2.3 & 27.2 \\ 12.0-12.9 & 6.5 & 13.2 & 32.8 \\ 13.0-13.9 & 24.2 & 38.8 & 16.6 \\ 14.0-14.9 & 35.8 & 30.8 & 2.8 \\ 15.0-15.9 & 23.8 & 9.4 & - \\ 16.0-16.9 & 6.8 & 1.2 & -- \\ 17.0-17.9 & 1.3 & 0.1 & - \\ 18.0-18.9 & 0.2 & - & -\end{array}$

examined had a satisfactory haemoglobin concentration and that in a comparatively small percentage of both sexes the results were definitely pathological, we are faced with the usual haematological difficulty of deciding what is to be regarded as an average normal figure. It was decided to adopt Wintrobe's (1942) standard of $14.5 \mathrm{~g} . / 100 \mathrm{ml}$. for the men and to regard anyone who reached $90 \%$ of this, i.e. $13 \mathrm{~g} . / 100 \mathrm{ml}$, as being within the normal range. A figure of $13 \mathrm{~g}$. might not be entirely satisfactory but, on the other hand, its occurrence in a few cases might be evidence of some temporary condition rather than of an established haemoglobin deficiency. On this basis $7.9 \%$ of all the males examined had a haemoglobin of less than $90 \%$ and only $\mathrm{x} \cdot 4 \%$ were under $80 \%$.

For women it is usual to place the average normal figure at about $14.0 \mathrm{~g} . / 100 \mathrm{ml}$, and on this basis we may perhaps regard $12.5 \mathrm{~g} . / 100 \mathrm{ml}$. (approx. $90 \%$ of 14 ) as being the lowest value within the normal range. An examination of the group with values of $12.0-12.9 \mathrm{~g} . / 100 \mathrm{ml}$. showed that about one-third of that group, or about $4.5 \%$ of the total, was below this rather arbitrary normal level. 'Therefore in the whole sample of females examined I I \% had a haemoglobin of less than $90 \%$ of normal and in $6.5 \%$ the value was $80 \%$ or less.

On the other hand, Wintrobe would regard a haemoglobin of $12 \mathrm{~g} . / 100 \mathrm{ml}$. as being normal in a woman, and on this basis only $6.5 \%$ of the females examined would be regarded as anaemic.

'Table 2 shows the distribution of plasma-protein values amongst the adult males and females examined. The minimum normal figure for plasma protein is usually placed at $6.0 \mathrm{~g} . / 100 \mathrm{ml}$. and if we accept that figure, only $0.3 \%$ of the males and $0.2 \%$ of the females were suffering from hypoproteinaemia.

The figures for haemoglobin and plasma protein in this group were, on the whole, satisfactory and agreed fairly well with the dietary survey findings of adequate intakes of iron and protein in the population as a whole (Jessop, 1950).

As might be expected the pregnant women showed much lower levels of haemoglobin than those not pregnant. Many authorities, however, regard the occurrence of a 
Table 2. Distribution of plasma-protein values for men and non-pregnant and pregnant women

\begin{tabular}{|c|}
\hline $\begin{array}{c}\text { Plasma } \\
\text { protein } \\
\text { (g./100 ml.) }\end{array}$ \\
\hline $\begin{array}{l}5 \cdot 0-5 \cdot 4 \\
5 \cdot 5-5 \cdot 9 \\
6 \cdot 0-6 \cdot 4 \\
6 \cdot 5-6 \cdot 9 \\
7 \cdot 0-7 \cdot 4 \\
7 \cdot 5-7 \cdot 9 \\
8 \cdot 0-8 \cdot 4 \\
8 \cdot 5-8 \cdot 9\end{array}$ \\
\hline
\end{tabular}

Men
$(378)$
(percentage
of total)
0
0.3
2.4
15.9
47.1
26.2
7.0
1.0

Women
(553)
(percentage
of total)
0
0.2
0.2
4.0
26.6
50.9
17.0
1.2

Pregnant
women $(300)$
(percentage
of total)
$1 \cdot 0$
$7 \cdot 0$
$38 \cdot 5$
$39 \cdot 5$
$12 \cdot 5$
$1 \cdot 5$
-

moderate degree of anaemia during pregnancy as physiological, and a figure of $10 \mathrm{~g} . /$. $100 \mathrm{ml}$. is taken as the lowest limit of normality. On this basis $8.2 \%$ of the subjects examined were suffering from a more severe grade of anaemia than could be accounted for by their pregnancy.

The plasma-protein values for pregnant women were also lower than those for the subjects in the first group, but only $8 \%$ fell below the accepted lowest level for the normal adult. If, as is generally agreed, the haemoglobin concentration is lowered because of hydraemia this condition would also depress the plasma-protein concentration so that we might be justified in regarding a figure of $5.5 \mathrm{~g} . / 100 \mathrm{ml}$. as representing a physiological hypoproteinaemia. On this basis only I \% of our subjects would fall below the normal range.

This work was carried out with the aid of a grant from the Medical Research Council of Ireland.

\section{REFERENCES}

Department of Health (Republic of Ireland) ( $1949 a$ ). Methods of Dietary Survey and Results from Dublin Investigation. Dublin: The Stationery Office.

Department of Health (Republic of Ireland) (1949b). Dietary Survey of the Congested Districts. Dublin: The Stationery Office.

Department of Health (Republic of Ireland) (r 950 a). Dietary Surcey of Large and Small Touns. Dublin: The Stationery Office.

Department of Health (Republic of Ireland) (1950b). Dietary Survey of Farming Families. Dublin: The Stationery Office.

Jessop, W. J. E. (1950). Brit. Ұ. Nutrit. 4, 281.

Phillips, R. A., Van Slyke, D. D., Dole, V. P., Emerson, K. Jr., Hamilton, P. B. \& Archibald, R. M. (r945). Copper Sulfate Method for Measuring Specific Gravities of Whole Blood and Plasma. New York: Josiah Macy Jr. Foundation.

Wintrobe, A. M. (1942). Clinical Haematology. London: Henry Kimpton.

\section{Results of Rickets Surveys in Dublin}

By W. J. E. Jessop, Royal College of Surgeons in Ireland, St Stephen's Green, Dublin

During the autumn of 1942 radiologists and clinicians noticed a rise in the incidence of rickets in Dublin. Between September 1940 and February 1942, the extraction rate of flour had been increased from its prewar level of $70-72 \%$ to $100 \%$ and Harrison \& Mellanby (1939) and McCance \& Widdowson (1942-3) had shown that this might have a very adverse effect on calcium absorption. In addition, the importation of cod- 